\title{
sciendo
}

Research Article

(c) 2018 Fountzoulas et.al. This is an open access article licensed under the Creative Commons Attribution-NonCommercial-NoDerivs License (http://creativecommons.org/licenses/by-nc-nd/3.0/).

\section{Critical Literacy and the Multiliteracies of Dance: A First Approach \\ Giorgos K. Fountzoulas}

School of Physical Education and Sports Science, National and Kapodistrian University of Athens, Athens, Greece

\section{Maria I. Koutsouba}

School of Physical Education and Sports Science, National and Kapodistrian University of Athens, Athens, Greece

\section{Evgenia Nikolaki}

School of Physical Education and Sports Science, National and Kapodistrian University of Athens, Naousa, Greece

Doi: 10.2478/jesr-2018-0032

\section{Abstract}

Greek traditional dance's transition from its "first" to the "second" existence took place in the context of the urbanization as this took place in Greece. This transition was accompanied, among others, with its teaching into a classroom that had to follow the principles governing every educational process. In this new context, the dance teaching is subject to literacy processes, which, in this case, are related to a literacy of dance and therefore of culture, that is to a dance and cultural literacy. The aim of this study is to look at dance as an educational subject that can lead to critical literacy through dance's multiliteracies as a synthesis of dance, movement, cultural and art literacy, with specific reference to Greek traditional dance. For this, literature-based research methodology is adopted that includes analysis and evaluation of relevant published literature. The literature review showed that Greek traditional dance, in the modern education framework, can be perceived in the light of critical literacy based on its multiliteracies, which are related to the concepts of movement, dance, art and cultural literacy.

Keywords: Greek traditional dance, Dance literacy, Multiliteracies, Critical literacy

\section{Introduction}

Greek traditional dance as a means of expression and as a form of art, as an object of kinesthetic, sentimental and cognitive content, as performance and social phenomenon, is an essential element of modern cultural heritage (Koutsouba, 2007; Lykesas, 2002; Tyrovola, 1999) and, more specifically, of the so-called intangible cultural heritage (UNESCO, 2003) as this is expressed in the case of dance (Koutsouba, 2014; Niora, 2017). Its protection, according to UNESCO's convention for the safeguarding of the intangible cultural heritage (2003), constitutes a guarantee of continuing creativity of human thought. Greek traditional dance formulates society's practices and values in which it takes place and signals the beginning of further evolution, both through dance movement as final outcome and as a process (Koutsouba, 2009). 
Greek traditional dance's transition from its "first" to the "second" existence (Hoerburger, 1965, 1968; Nahachewsky, 1995, 2001; Keallinohomoku, 1972; Koutsouba, 1991, 1997, 2007, 2010, 2016, Charitonidis, 2017, 2018) took place in the context of the urbanization as this took place in Greece (Koutsouba, 2016). This transition was accompanied, among others, with its teaching into a classroom that had to follow the principles governing every educational process. In other words, it is subject to literacy processes, which, in this case, are related to a literacy of dance and therefore of culture, that is to a dance and cultural literacy (Koutsouba, 2016). This is because dance as cultural phenomenon that forms and is being formed by the cultural process through a perpetual dialectical relationship, constitutes cultural knowledge contributing as such to the understanding of cultural diversity (Koutsouba, 2004). Learning in classrooms, certainly concerns all those parameters of educational procedure, such as, teacher, student, teaching, learning, communication, etc. (Lionarakis, 2005).

On the other hand, the concept of literacy has become an issue of interest in present days not only in the field of education but also in society in general, specifically in the light of critical literacy. More specifically, the argument that the process of learning is a longtime process starting from the birth throughout a person's life is increasingly gains ground these days. This is because of the dissemination of information that takes place in a faster and more intense way, and due to the constantly change of the market requirements. On this basis, all learning activities in which a person participates throughout his/her life aim at the improvement of his/her knowledge, skills and attitude in a personal, social and professional standard relating to formal, non-formal and informal education. Based on the above, dance and its relationship to literacy formulated the stimulus of this study.

\section{Aim of the Study}

The aim of this study is to look at dance as an educational subject that can lead to critical literacy through dance's multiliteracies as a synthesis of dance, movement, cultural and art literacy, with specific reference to Greek traditional dance.

\section{Methodology}

The methodological practice of this study is that of literature-based research methodology, including the analysis and evaluation of relevant published literature (Thomas \& Nelson, 2003). This particular research process, based on secondary bibliographical references (Paraskevopoulos, 1993), aims at pointing out the way in which the concept of critical literacy can be developed through dance, movement, cultural and art literacy, in the broader context of multiliteracies of Greek traditional dance.

\section{Meaning of Literacy}

Literacy has several and different meanings both throughout time and during same periods of time. In an attempt to delimit its meaning, one will find many different approaches over the years (Katsouli, 2012; Katsouli \& Koutsouba, 2013; Koutsouba, 2016), since the definition of this particular term constitutes a complicated process as researchers suggest multiple conceptualizations and interpretations (Aidinis \& Kostouli, 2001; Baynham, 2002; Cope \& Kalanztis, 1993, 2000; Darakli, 2009; Gee, 2006; Goodman, 1986; Gregory \& Cahill, 2009; Hasan, 2006; Katsouli, 2012; Katsouli \& Koutsouba, 2013; Koutsouba, 2016; Matsangouras, 2007; Mitsikopoulou, 2001; Papoulia-Tzelepi, 2001; Rockhill, 2000; Trokalli, 2014).

Literacy is a social institution, a complex phenomenon combining various cultural, social, historical and cognitive perspectives. Because of that, literacy becomes a subject of study in many disciplines such as anthropology, psychology, pedagogy, text linguistics etc. Therefore, different views and suggestions have been expressed concerning literacy, depending on each researcher's theoretical field and scientific background as well as on the factors that each field considers important (Aidinis \& Kostouli, 2001) since "...the meaning of literacy differs, yet it is a whole grid of 
ideological stands, which jointly compose the educational 'dispute' over literacy..." (Baynham, 2002:17).

The meaning of literacy initially was associated with the ability to read and write (Baynham, 2002; Kress, 1993; Mitsikopoulou, 2001; Chatzisavvidis, 2003, 2005, 2007). Later, a connection between this particular meaning and the society took place, in the context of which it was considered as an integral part of the sociopolitical framework (Baynham, 2002). Since the 1980's, the meaning of literacy acquired strong social dimensions (Gee, 2000), because of the transition from the perception of language as a means of expressing individual ideas and notions, to the consideration that language is a source of socially defined meanings (Halliday, 1989). On these grounds, a new interdisciplinary field was revealed, namely the New Literacy Studies (Barton, 1994; Halliday, 1989; Halliday, \& Hasan, 1989; Street, 1993, Gee, 1996). What is marked by this field is that literacy should be considered a socio-cultural practice and not as a sum of skills obtained by a person (Maybin, 2000), thus reinforcing the critical dimension of literacy introduced by Freire (1963).

Nowadays, the "traditional" view concerning exclusively literacies of linguistic form has been overpassed (Baynham, 2002), allowing the extension of this term to visual, technological, computing and even cultural literacy (Baynham, 2002). Literacy research in social context led to the conclusion that there should be no discussion on the term literacy, but on the term literacies in the context of a specific locality/ideology (Baynham, 2002).

\subsection{Critical literacy}

The beginning of critical literacy is doubt (Kress, 1997). By emphasizing in social goals and context, it aims at the public's sensitization in the functions of literacy's dominant forms and at the development of critical thinking towards them, since from this point of view the meaning of literacy is neutral (Freire, 1985). Therefore, the students can potentially use different kinds of speech and realize the way of constructing their notions by obtaining access to socially powerful meanings, the practices by which they are constructed and the opportunity to challenge them (Freire, 1998). In other words, the aim of education, through critical literacy, is for the students to understand the importance of speaking and writing in their everyday life, in the formation of culture and its strength as cause of liberation (Barton, 1994; Baynham, 2002; Gee, 1996; Halliday, 1989; Halliday, \& Hasan, 1989; Harasim, 1983; Koutsouba, 2016; Mitsikopoulou, 2001; Street, 1993; Chatzisavvidis, 2003, 2005, 2007).

Critical literacy is not a static concept, but a dynamic process. One cannot therefore talk only about literacy since the subject of discussions should be on "literacy practices" (Baynham, 2002) too. In this way, one can explore the values relied on it and the surrounding ideologies, thus indicating the social and ideological nature of reading and writing (Maybin, 2001). Even though it is considered by some as a radical and, at the same time, utopian movement (Maybin, 2001; Mejia, 2004), critical literacy fights for every person and the society in total trying to utilize the dynamic relationship among education, thinking, language and reality (Freire \& Macedo, 1987), critically facing "...the process of knowledge, teaching, learning, reading, writing and studying..." (Gadotti \& Torres, 2009:63).

In this way, the most important point of critical literacy is reflected by transforming the learning process into a continuous act of knowledge (Koutsouba, 2016), thus creating an "authentic conversation" (Gregory \& Cahill, 2009) between the subjects of knowledge, i.e. the teacher and the student (Freire, 2000; Freire \& Macedo, 1987). For Freire, the "father" of critical literacy, critical literacy cultivates through education "...the critical consciousness of teachers and students with the combination of thought with action and experience..." (Freire, 1976:10), attaching in a sense the critical thinking to the educational process. The student now turns from an object into an active subject assisting in his/her own liberation (Freire, 1976, 1997; Koutsouba, 2016; Xochellis, 1990, 1997; Perraki, 2007).

Today, any kind of educational process is directly associated with critical literacy (Harmon \& Wood 2001; Lemke 1990), that is with a critical reading, first, of one's self and, then, of the world surrounding him (Freire, 1976; Baynham, 2002). Teaching is considered an essential precondition 
for the student so as him/her to be able to turn into a critical "reader" (Freire, 1976; Baynham, 2002).

\subsection{Movement literacy}

Movement literacy constitutes the mechanism with which education can be seen in a holistic way as coordination between mind and body (Metheny, 1968; Arnold, 1979; Gardner, 1983; Whitehead, 1990; Matthews, 1998; Jurbala, 2015), a coordination that occurs in all learning activities (Kentel \& Dobson, 2007). The "traditional" pedagogy's point of view of education is thereby explored and positive behaviors are promoted towards natural activity and healthy lifestyle (Higgs, 2010; Roetert \& MacDonald, 2015; Tremblay \& Llyod, 2010; Whitehead, 2001, 2010).

In particular, the kinetically literate person: a) responds fluently to a wide range of kinetic activities (Higgs, Balyi, Way, Cardinal, Norris, \& Bluechardt, 2008), b) has positive self-awareness and self-esteem (Chen, 2015; Quested, Duda,. \& Balaguer, 2013) and c) has strong inner motivation for participation in kinetic activities (Chen, 2015; Haerens, Vansteenkiste, Aelterman, Van den Barghe, Cardon, \& Tallir, 2013; Quested, Duda \& Balaguer, 2013). As a result, movement literacy represents a dynamic state (Taplin, 2013) which is redefined, depending on one person's life conditions at the time (Whitehead, 2013) and is associated with learning skills and communication acquisition (Ennis, 2015).

More specifically, the meaning of movement literacy includes the notions of learning through movement, learning about movement and learning because of movement (Kentel \& Dobson, 2007; Whitehead, 2001, 2007, 2010), a position that points out the importance of understanding the mechanical principles related to the body in order this to be able to "read" the environment and, therefore, the entire society (Giblin, Collins, \& Button, 2014; Whitehead, 2001). Such a position reveals a multidimensional theory (Corbin, 2016) that focuses on the balanced human development envisaged as an amalgam of kinetic, sentimental and cognitive (Mandigo, Francis, Lodewyk, Lopez $\& \mathrm{PhEd}, 2009$ ) that leads to the conscious adoption of a kinetically active lifestyle (Whitehead, 2013).

\subsection{Cultural literacy \& art literacy}

Cultural literacy constitutes the network of information that all capable "readers" own. More specifically, the information given in a text is considered to be the "tip of the iceberg", since its main part is offered by the reader him/herself (Anning, 2010; Hirsch, 1983, 1987). Therefore, each reader's socio-cultural background is of great importance for the process of text comprehension (Anning, 2010; Hirsch, 1983, 1987). Moreover, cultural literacy is advantageous for both the individual and the society, since the individual acts in a society and, at the same time, he/she receives the action of this society (Anning, 2010; Hirsch, 1983).

More specifically, cultural literacy contributes to the individual interaction with others, particularly when the latter have a different socio-cultural background so as to develop a critical cultural stance. In other words, instead of taking his/her own cultural beliefs and practices for granted and considering them as 'normal', an individual can place them in the context of other cultures in order to assess their strength and limitations (Flavell, Thackrah \& Hoffman, 2013). On this basis, cultural literacy contributes to the socially reducing prejudice based on culture and to the increasing of the value of diversity and the participation in social practices.

Furthermore, part of cultural literacy is considered to be art literacy. Art literacy is defined as the individual's ability to understand and contribute to the surroundings associated with art in general (Albers, 1997; Albers, \& Harste, 2007; Barbousas, 2014; Barton, 2014; Livermore, 2003; Vaughan \& Caldwell, 2014), with visual and theatre arts (Stinson, 2104), with music (Davidson, 2014) and with dance (Ashley, 2013; Foster, 1976; Leonard, Hall, \& Herro, 2015; Jones, 2014; Koutsouba, 2016).

In particular, an individual should be "fluent" in arts in order to be considered artistically and culturally literate. According to Barton (2014), in order to own the fluency of the creator and the recipient, one must "...know what affects him and how to be the master of the method, be intimately 
aware of the means and the way and understand the social and cultural practices in which art was created or is being observed..." (p. 12). Multiple art dialectics are placed under control through this process. Furthermore, the individual has the potential not only to express him/herself, but also to define his/her identity (Barton, 2014).

\subsection{Dance literacy}

Dance, apart from art, is also a non-verbal communication (Giurchescu, 1994; Dimopoulos, 2009; Hanna, 2008; Koutsouba, 1991, 1997; Kyriakakis, 2004) and, as an educational subject, is associated with dance literacy (Ashley, 2013; Buck, 2003; Dils, 2007; Koutsouba, 2016; Leonard, Hall, \& Herro, 2015; Hong, 2000; Jones, 2014). In particular, dance literacy entails corporeal knowledge. This knowledge is physically experienced and articulated through dance (Ashley, 2013), since "...the essence of this embodied experience is a transcendental quality which contributes to the universality of dance..." (Jones, 2014:111). In other words, dance is literacy since it has its own vocabulary, uses its own grammar and is based on semantics as all "traditional" literacy forms do (Leonard, Hall, \& Herro, 2015).

Dance literacy represents substantive and abstract concepts of dance (Manning, 2007) as dance constitutes a "...cultural phenomenon that forms and is being formed by the cultural process through a perpetual dialectical relationship... [and) cultural knowledge contributing to the understanding of cultural diversity..." (Koutsouba, 2004:76). This particular physical knowledge enables the creation of meaning, of expression, of critical thinking and analysis (Leonard, Hall, \& Herro, 2015). In particular, "...dance as a literacy form has unique potential and perspective in schools as embodied cognition and as form of research; it is a way of creating autonomy and representative knowledge because the dance body serves as subject and object, acting and action, writer and writing, speaker and speaking, self and self-expression..." (Leonard, Hall, \& Herro, 2015:339).

\subsection{Multiliteracies of dance}

Nowadays, the rapid evolution of new technologies has resulted in the multiplication of communication media that radically changed the way of communicating between people and nations, and formed a new reality that requires both new ways of approaching literacy as well as the development of new skills necessary for its approaching and understanding (Cope \& Kalanztis, 2000 , Kress, 2003). Because of these, the notion of literacy is related to that of multiliteracies (New London Group, 1996; Kress, 1998, 2003) where language, as a socio-cultural practice, points out the multimodality of meanings (Kress, 2003) through polymorphic and multicultural social environments (Cope \& Kalanztis, 2000; Kress \& van Leeuwen, 1996).

Thus, the pedagogy of multiliteracies is concerned not only with linguistic ways of representation (New London Group, 1996), but, in a wider sense, with ways related to the cognitive, cultural and social domains (Cope \& Kalanztis, 2000). In this kind of pedagogy, learning constitutes “...a dynamic process, an action of students and teachers' meeting with other sources of understanding the world apart from the linguistic, such as sound or optical sources..." (Trokalli, 2014:14).

\section{Discussion}

Nowadays, the points of view that support that learning is a longtime process starting from birth and continuing throughout one's life are increased. More specifically, in the age of information and communication technology (ICT), the society's demands of are rapidly changed. As a result, the educational programs in order to adjust to the demands of today's society have to aim at the creation of critical readers, that is to the creation of critical readers of themselves and of their society. In modern educational contexts, the "traditional" view concerning exclusively literacies of linguistic form (Baynham, 2002) is not sufficient since visual, technological, computing, cultural and other kinds of literacy are necessary (Baynham, 2002; Freire, 1976). Dance, a kind of literacy by 
itself as well as a synthesis of other literacies (movement, cultural, art etc.) seems to have the ability to correspond to the contemporary needs of education. This is because dance has unique power of embodied cognition (Leonard, Hall, \& Herro, 2015) with body can being transmitter and message receiver at the same time.

Moreover, traditional dance forms as that of Greek traditional dance, enhance dance's multiliteracies, that is dance, movement, art and cultural literacy (Koutsouba, 2016). In particular, traditional dance forms as that of Greek traditional dance constitute: a) movement literacy since movement is engaged, b) cultural literacy since it is a cultural phenomenon of a particular society at a particular time and space, c) art literacy, since it constitutes a performing art and d) dance literacy since through dance the body acts both as the transmitter as well as the message receiver (Table 1).

Table 1: (Greek traditional) dance and literacy

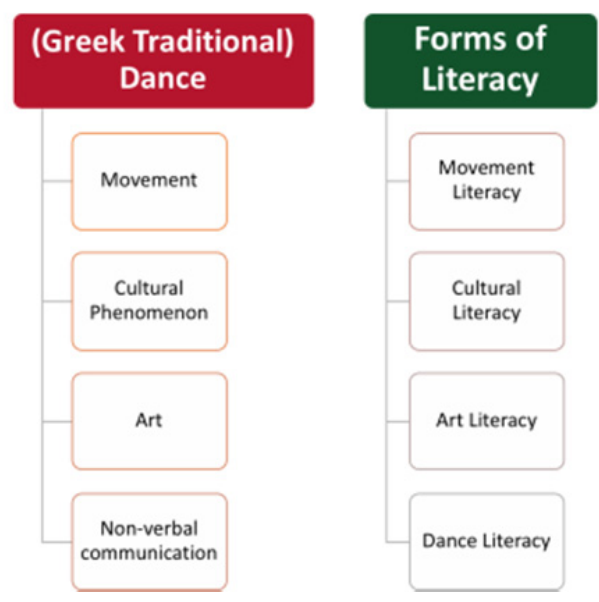

Based on the above, movement, cultural, art and dance literacy constitute the multiliteracies of dance and in particular of Greek traditional dance. The meaning of literacy concerns more and more people these days, not only in the field of education but also in society in general, specifically in the light of the values of critical literacy that contribute in the development of critical thinking of one's self and then of the world surrounding him/her. Therefore, since the individual uses his/her body to "read" and critically face his/her existence in the world, dance literacy should not be absent from the discussion on critical literacy. This discussion breaks new ground for dance per se.

Table 2: Multiliteracies of (Greek traditional) dance

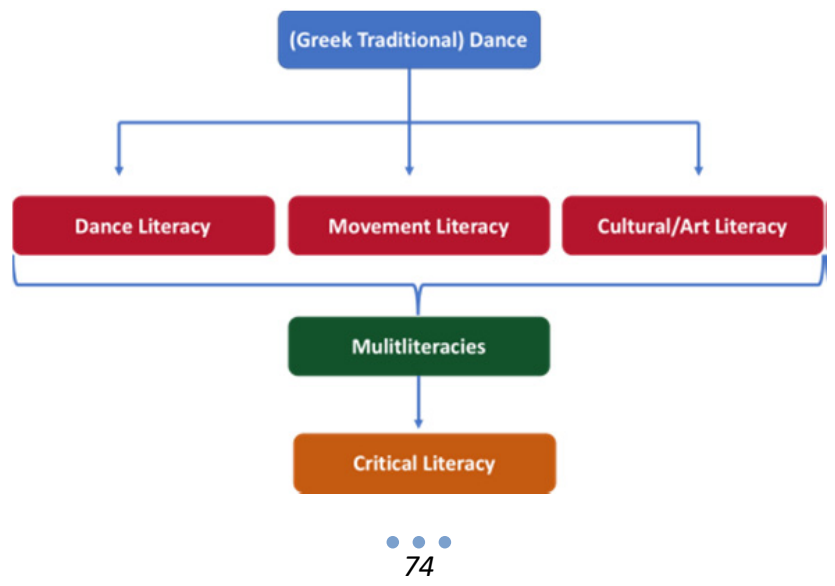




\section{References}

Aidinis, A., \& Kostouli, T. (2001). Literacy Models: Theoretical approaches and education practice. Virtual School, The Sciences of Education Online vol. 2, issues 2-3.

Anning, B. (2010). Embedding an Indigenous Graduate Attribute into University of Western Sydney's courses. The Australian Journal of Indigenous Education, 39(Supplementary), 40-52. doi: 10.1375/S1326011100001125.

Albers, P. Art as literacy. Language Arts, 74(5), 338-350.

Albers, P., \& Harste, J.C. (2007). The arts, new literacies, and multimodality. English Education, 40(1), 6-20.

Arnold, P. (1979). Meaning in movement, sport and physical education. London: Heinemann.

Ashley, L. (2013). Let's get creative about creativity in dance literacy: why, why not, and how?, Journal of Movement Arts Literacy 1(1), 1-11.

Barbousas, J. (2014) Visual arts education and the formation of literacies: an exploration of visuality. In: G. Barton (ed.), Literacy in the Arts: Retheorising Learning and Teaching (pp. 39-54). Switzerland: Springer International Publishing.

Barton, D. (1994). Literacy: an introduction to the ecology of written language. Oxford: Blackwell.

Barton, G. (2014) Literacy and the arts: interpretation and expression of symbolic form. In: G. Barton (ed.), Literacy in the Arts: Retheorising Learning and Teaching (pp. 3-20). Switzerland: Springer International Publishing.

Baynham, M. (2002). Literacy practices (trans. M. Arapopoulou). Athens: Metaichmio.

Buck, R. (2003). The language of dance. In J. Livermore (ed.), More than words can say. A view of literacy through the Arts (pp. 23-33). Canberra: Australian Centre for Arts Education.

Charitonidis C. (2017). The "re-urbanization" of an expatriated dance culture. The Greek dance-house in Hungary. In K. Stepputat (ed.), Dance, Senses, Urban Contexts, Proceedings from the 29th Symposium of the Study Group on Ethnochoreology (pp. 340-346). Graz: Institute of Ethnomusicology, University of Music and Performing Arts.

Charitonidis C. (2018). "Parallel" lives and traditions: the Greek dance-house in Hungary. Master dissertation. DPESS, University of Athens, Athens.

Chatzisavvidis S., (2003). Multiliteracies and Teaching of Modern Greek. In Language and its Teaching (pp. 189-196). Florina: Vivliologion.

Chatzisavvidis S., (2005). From the pedagogy of literacy to multiliteracies: new trends, dimensions and perspectives in language teaching. In Balaskas and Angelakos (eds.), Language and Literature in Primary and Secondary Education (pp. 35-52). Athens: Metaichmio.

Chen, A. (2015). Operationalizing physical literacy for learners: Embodying the motivation to move, Journal of Sport and Health Science, 4(2), 125-131.

Cope, B., \& Kalantzis, M. (1993). The powers of literacy: a genre approach to teaching writing. London: Falmer Press.

Cope, B., \& Kalantzis, M. (2000). Multiliteracies: literacy learning and the designing of social futures. London: Rutledge.

Corbin, C. (2016). Implications of physical literacy for research and practice: a commentary, Research Quarterly for Exercise and Sport, 87(1), 14-27.

Darakli, H. (2009). Emergent Literacy-first reading and writing: a connection framework of preschool and primary school age. Master thesis. Thessaloniki: School of Primary Education, Aristotle University of Thessaloniki.

Davidson, R. (2014). Music literacies: teaching diversity. In: G. Barton (ed.) Literacy in the Arts: Retheorising Learning and Teaching (pp. 161-175). Switzerland: Springer International Publishing.

Dils, A. (2007). Why dance literacy?, Journal of the Canadian Association for Curriculum Studies, 5(2), 95-113.

Dimopoulos, K. (2009). Ritual, symbolism and communication. The celebration of the third day of Easter in the community of Lazarina Karditsa in Thessaly. In Proceedings from the $17^{\text {th }}$ International Congress of Physical Education and Sport Sciences. Komotini: Department of Physical Education and Sports Science, Democritus University of Thrace.

Ennis, C.D. (2015). Knowledge, transfer, and innovation in physical literacy curricula, Journal of Sport and Health Science, 4(2), 119-124.

Flavell, H., Tharckrah, R., \& Hoffman, J. (2013). Developing indigenous Australian cultural competence: a model for implementing indigenous content into curricula. Journal of Teaching and Learning for Graduate Employability, 4(1), 39-63).

Foster, R. (1976). Knowing in my bones. London: A and C Black Ltd.

Freire, P. (1976). Education, the practice of freedom. London: Writers and Readers Publishing Cooperative.

Freire, P. (1985). The politics of education: culture, power, and liberation. South Hadley: Mass., Bergin \& Garvey. 
Freire, P. (1997). Mentoring the mentor: a critical dialogue with Paulo Freire. New York: P. Lang.

Freire, P. (1998). Pedagogy of freedom: ethics, democracy and civic courage. U.S.A.: Lanham, Rowman \& Littlefield Publishers.

Freire, P., \& Macedo, D. (1987). Literacy: reading the word and the world. Hadley, MAL Bergin and Garvey.

Gadotti, M. \& Torres C.A. (2009). Paulo Freire. Education for development. Development and change, 40(6), $1255-1267$.

Gardner, H. (1983). Frames of mind: the theory of multiple intelligences. New York: Basic Books.

Gee, J.P. (1996). Social linguistics and literacies: Ideology in discourses. London: Taylor \& Francis.

Gee, J.P. (2000). The new literacy studies: from socially situated to the work of the social. In D. Barton, M. Hamilton \& R. Ivanic (eds.), Situated literacies. Reading and Writing in Context (pp. 180-196). London \& New York: Routledge.

Gee, J.P. (2006). Literacy and the myth of literacy: from Plato to Freire. In A. Charalambopoulos (ed.) Literacy, society and education (pp. 15-54). Thessaloniki: Institute of Modern Greek Studies.

Giblin, S., Collins, D., \& Button, C. (2014). Physical literacy: importance, assessment and future directions. Sports Medicine, 44(9), 1177-1184.

Giurchescu, A. (1994). The Power and the Dance Symbol and its Sociopolitical Use. In I. Loutzaki (ed.), Dance and its Socio-Political Aspects. Dance and Costume, Proceedings from the 17th Symposium of the Study Group on Ethnochoreology (pp. 15-23). Nafplion: Peloponnesian Folklore Foundation \& International Council for Traditional Music.

Goodman, Y., (1986). Children coming to know literacy. In W. Teale \& E. Sulzby (eds.), Emergent literacy: Writing and reading (pp. 1-14). Norwood, NJ: Ablex.

Gregory, A. \& Cahill, M.A. (2009). Constructing critical literacy: Self-reflexive ways for curriculum and pedagogy. Critical Literacy: Theories and Practices, 3(2), 6-16.

Haerens, L., Vansteenkiste, M., Aelterman, N., Van den Barghe, L., Cardon, G. \& Tallir, I. (2013) Physical Education teachers inspiring young people towards a physically active lifestyle?! Motivational dynamics in Physical Education, International Council of Sport Science and Physical Education Bulletin, 65, 155-166.

Halliday, M.A.K., \& Hasan, R. (1989). Language, context, text: aspects of language in a social-semiotic perspective. Oxford: Oxford University Press.

Halliday, M.A.K. (1989). Spoken and written language. Oxford: Oxford University Press.

Hanna, J. (2008). A nonverbal language for imagining and learning: Dance education in K-12 curriculum. Educational Researcher, 37(8), 501-502.

Harasim, L. (1983). Literacy and National Reconstruction in Guinea-Bissau. A Critique of the Freirian Literacy Campaign. PhD thesis, University of Toronto, Toronto.

Harmon, J.M. \& Wood, K.D. (2001). The TAB Book Club Approach: Talking (T) About (A) Books (B) in content area classrooms. Middle School Journal, 32(3), 51-56.

Hasan, R. (2006). Literacy, everyday talk and society. In A. Charalambopoulos. (ed.) Literacy, society and education (pp. 134-189). Thessaloniki: Institute of Modern Greek Studies.

Higgs, C., Balyi, I., Way, R., Cardinal, C., Norris, S., \& Bluechardt, M. (2008). Developing physical literacy: a guide for parents of children ages 0 to 12. Vancouver: Canadian Sports Centre.

Higgs, C. (2010). Physical literacy-Two approaches, one concept. Literacy, 6(2), 127-138.

Hirsch, E. (1983). Cultural literacy. The American Scholar, 52(2), 159-169. Retrieved 9.1.2018 from: http://www.jstor.org/stable/41211231

Hirsch, E. (1987). Cultural literacy: What every American should know. Boston: Houghton Mifflin.

Hirsch, E., Joseph, K., \& James T. (2002). The new dictionary of cultural literacy. Boston \& New York: Houghton Mifflin Company.

Hong, T. (2000). Developing dance literacy in the postmodern: An approach to curriculum. Arts Online. Retrieved 24.4.2017 from: http://artsonline.tki.org.nz/.

Jones, E. (2014). Dance literacy: An embodied phenomenon. In: G. Barton (ed.) Literacy in the Arts: Retheorising Learning and Teaching (pp. 111-129). Switzerland: Springer International Publishing.

Jurbala, P. (2015). What is physical literacy, really? Quest, 67(4), 367-383.

Katsouli, I. (2012). Distance learning and critical literacy: an example of literary text. Dissertation. Patra: H.O.U.

Katsouli, I. \& Koutsouba, M. (2013). Politics and education, education and politics: The "conversation" between critical literacy and open and distance learning. In Proceedings from the $7^{\text {th }}$ Conference for the Open \& Distance Learning "Learning Methodologies" (pp. 59-69). Athens: Hellenic Network of Open and Distance Learning Publications.

Kentel, J.A., \& Dobson, T. (2007). Beyond myopic visions of education: revisiting movement literacy. Physical Education and Sport Pedagogy, 12(2), 145-162.

Koutsouba, M. (1991). The Greek Dance Groups of Plaka. A Case of 'airport art'. MA. Dissertation. UK: Department of Dance, University of Surrey.

Koutsouba, M. (1997). Plurality in Motion: Dance and Cultural Identity on the Greek Ionian Island of Lefkada. Ph.D. thesis. London: Music Department, Goldsmiths College, University of London. 
Koutsouba, M. (2004). The contribution of teaching Greek traditional dance in modern Greek multicultural society. In E. Avdikos, R. Loutzaki \& C. Papakostas (eds.), Choreftika Eteroklita (pp. 213-226). Athens: Ellinika Grammata.

Koutsouba, M. (2016). Dance, critical and cultural literacy through the example of teaching Pontian dance. In Music-Dance-Costume, Proceedings from the $1^{\text {st }}$ Science Symposium of Pontic Culture (pp. 11-78). Athens: Primary Pontic Unions of Attica basin.

Kress, G. (1993). Learning to write. London: Routledge.

Kress, G. (1997). Before writing: rethinking the paths to literacy. London: Routledge.

Kress, G. (2003). Literacy in the new media age. London: Routledge.

Kyriakakis, I. (2004). The ethnographic experience and the critique of culture. An attempt to delineate the "anthropological perspective" as interpretive of human condition. In C. Dermetzopoulos, \& M. Spyridakis (eds.), Diversities: Anthropology, Culture and Politics (pp. 9-28) Athens: Metaichmio Publications.

Lemke, J. L. (1990). Talking science: Language, learning and values. Norwood, NJ: Ablex.

Leonard, A., Hall, A., \& Herro, D. (2015). Dancing literacy: expanding children's and teachers' literacy repertoires through embodied knowing. Journal of Early Childhood Literacy, 6(3), 338-360.

Liveromore, J. (2003). A view of literacy through the arts. In J. Livermore (ed.), More than words can say. A view of literacy through the Arts (pp. 5-17). Canberra: Australian Centre for Arts Education.

Mandigo, J., Francis, N., Lodewyk, K., Lopez, R., \& PhEd, (2009). Position paper: Physical literacy for educators. Physical and Health Education Canada.

Manning, E. (2007) Politics of Touch: Sense, Movement, and Sovereignty. Minneapolis: University of Minnesota Press.

Matthews, J.C. (1998). Somatic knowing and education, Educational Forum, 62(3), 236-242.

Matsangouras, I. (2007). School literacy. Functional, critical, scientific. Athens: Grigoris.

Maybin, J. (2000). The new literacy studies: context, intertextuality and discourse. In D. Barton, M. Hamilton \& R. Ivanic (eds.), Situated Literacies. Reading and Writing in Context (pp. 197-209). London \& New York: Routledge.

Maybin, J. (2001) The politics of literacy. In Linguistic Development, A textbook. (pp. 149-167). Patra: H.O.U.

Mejia, A. (2004). The problem of knowledge imposition: Paulo Freire and critical system thinking. Systems Research and Behavioral Science, 21, 63-82.

Metheny, E. (1968). Movement and meaning. New York: McGraw-Hill.

Mitsikopoulou, B. (2001). Literacy. In A. Christides (ed.), Encyclopedia for the Greek language (pp. 223-229). Thessaloniki: Centre for the Greek Language.

New London Group (1996). A pedagogy of multiliteracies: designing social futures. Harvard Education Review, $66,60-92$.

Niora, N. (2017). Learning and administration of Greek traditional dance - the case of a timeless in Greece. $\mathrm{PhD}$ thesis, DPESS, University of Athens, Athens.

Papoulia-Tzelepi, P. (2001). The new perspective of the emergent literacy. In Papoulia-Tzelepi, P. (ed.), Emergent literacy: Research and Practice (pp. 13-41). Athens: Kastaniotis.

Perraki, E. (2007). The educational theory of P. Freire in the light of feminist pedagogy. Master thesis. Thessaloniki: Aristotle University of Thessaloniki.

Quested, E., Duda, J.L. \& Balaguer, I. (2013). Promoting physical activity participation via more empowering sport experiences: The PAPA project, International Council of Sport Science and Physical Education Bulletin, 65, 177-182.

Rockhill, K. (2001). Social gender, language and the politics of Literacy. In Linguistic development, language and literacy in social practice, vol. C. (pp. 285-302). Patra: H.O.U.

Roetert, E. P., \& MacDonald, L. C. (2015). Unpacking the physical literacy concept for K-12 physical education: What should we expect the learner to master? Journal of Sport and Health Science, 4(2), 108-112.

Stinson, M. (2014). Drama literacy: (In)definite article. In: G. Barton (ed.) Literacy in the Arts: Retheorising Learning and Teaching (pp. 131-143). Switzerland: Springer International Publishing.

Street, B. (1993). Cross-cultural approaches to literacy. Cambridge: Cambridge University Press.

Taplin, L. (2013). Physical literacy as a journey. Journal of Sport science and Physical Education, 65, 57-63.

Thomas, J.R., \& Nelson, J.K. (2003). Research methods in physical activity. (trans. K. Karteroliotis). Athens: Medical Publications P.C. Paschalidis.

Tremblay, M., \& Llyod, M. (2010). Physical Literacy Measurement. The Missing Piece. Physical \& Health Education Journal, 76(1), 26.

Trokalli, A. (2014). The teaching of multimodality in the educational software for language teaching in compulsory education. Master thesis. Patra: School of Humanities and Social Sciences, Department of Primary Education.

UNESCO (2003). Convention for the Safeguarding of the Intangible Cultural Heritage. Retrieved 15.4.2017 from: http://portal.unesco.org/en/ev.php-URL_ID=17716\&URL_DO=DO_TOPIC\&URL_SECTION=201.html 
Vaughan, T. \& Caldwell, B. (2014). Improving literacy through the arts. In: G. Barton (ed.) Literacy in the Arts: Retheorising Learning and Teaching (pp. 203-215). Switzerland: Springer International Publishing.

Whitehead, M. (1990). Meaningful existence, embodiment, and physical education, Journal of Philosophy of Education, 24(1), 3-13.

Whitehead M. (2001). The concept of physical literacy. European Journal of Physical Education, 2, 127-138.

Whitehead M. (2007). Physical literacy: philosophical considerations in relation to the development of self, universality and propositional knowledge. Sport Ethics Philosophy, 1, 281-298.

Whitehead M. (2010). Physical literacy: throughout the life course. London: Routledge.

Xochellis, P. (1990). Pedagogy. In Pedagogical, psychological encyclopedia - Dictionary (vol. 4, pp. 3599-3603). Athens: Ellinika Grammata.

Xochellis, P. (1997). Existential problems of pedagogy. In M. Vamvoukas \& A. Chourdakis (eds.), Pedagogy in Greece and in Europe: trends and perspectives, Proceedings from the $7^{\text {th }}$ International Conference, (pp. 76-84). Crete: Hellenic Educational Society \& University of Crete. 